BRITISH MEDICAL JOURNAL VOLUME $287 \quad 13$ AUGUST 1983

permission to include their patients in the study, Mr A Lawton for statistical advice, and the staff of the medical photography department for preparing the illustration.

\section{References}

${ }^{1}$ Rowan RM, Fraser C, Gray JH, McDonald GA. The Coulter Model S-Plus: the shape of things to come. Clin Lab Haematol 1979;1:29-40.

${ }^{2}$ Karpatkin S. Heterogeneity of human platelets. II. Functional evidence suggestive of young and old platelets. $\mathcal{F}$ Clin Invest 1969;48:1083-7.

${ }^{3}$ Karpatkin S. Heterogeneity of human platelets. VI. Correlation of platelet function with platelet volume. Blood 1978;51:307-16.

4 Haver VM, Geor ARL. Functional fractionation of platelets. $\mathcal{f}$ Lab Clin Med $1981 ; 97: 187-204$.

${ }^{5}$ Kraytman $M$. Platelet size in thrombocytopenias and thrombocytosis of various origin. Blood 1973;41:587-98.

- Mannucci PM, Sharp MV. Platelet volume and shape in relation to aggregation and adhesion. Br $\mathcal{F}$ Haematol 1967;13:604-17.

' Hirsh J, Glynn MF, Mustard JF. The effect of platelet age on platelet adherence to collagen. 7 Clin Invest 1968;47:466-73.

${ }^{8}$ Nelson RB III, Kehl D. Electronically determined platelet indices in thrombocytopenic patients. Cancer 1981 ;48:954-6.

${ }^{9}$ Eldor A, Avitzour M, Or R, Hanna R, Penchas S. Prediction of haemorrhagic diathesis in thrombocytopenia by mean platelet volume. $\mathrm{Br} \mathrm{Med}$ f $1982 ; \mathbf{2 8 5}: 397-400$.

${ }^{10} \mathrm{Giles} \mathrm{C}$. The platelet count and mean platelet volume. $\mathrm{Br} \mathcal{F}$ Haematol $1981 ; 48: 31-7$.
${ }^{11}$ Enticknap JB, Gooding PG, Lansley TS, Avis PRD. Platelet size and function in ischaemic heart disease. 7 Atheroscler Res 1969;10:41-9.

12 Daniel S, O'Brien JR, John JA. Platelets in the prediction of thrombotic risk. Atheroscler 1982;45:91-9.

${ }^{13}$ Knudsen JB, Gormsen J, Skagen K, Amtorp O. Changes in platelet functions, coagulation and fibrinolysis in uncomplicated cases of acute myocardial infarction. Thromb Haemost $1979 ; 42: 1513-22$

${ }^{14}$ Schwartz MB, Hawiger J, Timmons S, Friesinger GC. Platelet aggregates in ischaemic heart disease. Thromb Haemost 1980;43:185-8.

${ }^{15}$ Mehta P, Mehta J. Platelet function studies in coronary artery disease. V. Evidence for enhanced platelet micro-thrombus formation activity in acute myocardial infarction. Am $\mathcal{F}$ Cardiol 1979;43:757-60.

${ }^{16}$ Dalal JJ, Penny WJ, Saunders KC, Sheridan DJ, Bloom AL, Henderson $\mathrm{AH}$. Platelet counts and aggregates in coronary artery disease. Eur Heart $\mathcal{f} 1982 ; 3: 107-13$.

17 Thompson CB, Eaton KA, Princiotta SM, Rushin CA, Valeri CR. Size dependent platelet subpopulations: relationship of platelet volume to ultrastructure, enzymatic activity, and function. $B r \mathcal{F ~ H a e m a t o l ~ 1 9 8 2 ; ~}$ 50:509-19.

${ }^{18}$ Heptinstall S, Mulley GP, Taylor PM, Mitchell JRA. Platelet-release reaction in myocardial infarction. $\mathrm{Br}$ Med $\mathcal{F} 1980 ; \mathrm{i}: 80-1$.

19 Pennington DG, Lee NLY, Roxburgh AE, McGready JR. Platelet density and size: the interpretation of heterogeneity. $\mathrm{Br} \mathbf{F}$ Haematol 1976;34:365-76.

20 Paulus JM. Platelet size in man. Blood 1975;46:321-36.

21 Chesebro JH, Fuster V, Byrne J. Improvement of shortened platelet survival half-life from the early to the late phase of myocardial infarction. Thromb Haemost $1981 ; 46: 143$.

(Accepted 1 fune 1983)

\title{
Failure of bromocriptine to maintain reduction in size of a macroprolactinoma
}

\author{
HARALD D BREIDAHL， DUNCAN J TOPLISS， JOHN W PIKE
}

\begin{abstract}
A patient with a macroprolactinoma was treated with bromocriptine $15 \mathrm{mg}$ daily. Both the size of the tumour as shown by computed tomography and the serum prolactin concentration decreased over several months but then increased. The dose of bromocriptine was increased to $40 \mathrm{mg}$ daily but tumour growth continued, and the tumour was resected. Production of prolactin by cultured cells was not inhibited by high concentrations of bromocriptine, suggesting that regrowth of the tumour was due to cells resistant to dopamine agonist action.

This case of regrowth of a prolactinoma during bromocriptine treatment after an initial reduction in size indicates the need for close surveillance especially of patients whose serum prolactin concentration fails to fall into the normal range with bromocriptine treatment.
\end{abstract}

\footnotetext{
Alfred Hospital, Melbourne 3181, Australia

HARALD D BREIDAHL, MD, FRCP, visiting endocrinologist, Ewen Downie metabolic unit

DUNCAN J TOPLISS, MB, FRACP, deputy director, Ewen Downie metabolic unit

JOHN W PIKE, MRACR, FRCR, visiting radiologist, department of radiological sciences

Correspondence to: Dr H D Breidahl, Ewen Downie Metabolic Unit, Alfred Hospital, Commercial Road, Prahran, Victoria 3181, Australia.
}

\section{Introduction}

Treatment with bromocriptine reduces the size of macroprolactinomas ${ }^{12}$ and is advocated as the initial treatment of choice. ${ }^{2}{ }^{3}$ Clearly, the tumour may enlarge when bromocriptine treatment is stopped, ${ }^{4}$ but no case has been reported in which the size of the tumour decreased initially with bromocriptine treatment but subsequently increased despite continuing treatment. We now report such a case.

\section{Case report}

A 47 year old man presented in November 1981 with a history of failing vision for five months and headaches for one month. Libido and potency had waned over the past five years, and he had had diminished energy and cold intolerance for several months. On examination he had reduced visual acuity (right 6/24, left 6/36) and bitemporal hemianopia. Both testes were soft and $12 \mathrm{ml}$ in volume.

$X$ ray examination of the skull showed an enlarged and eroded pituitary fossa. A computed tomograph of the head showed a large contrast enhancing pituitary tumour with suprasellar extension (fig (A)). Serum prolactin concentration was $135000 \mathrm{mU} / 1$ (normal $<500 \mathrm{mU} / \mathrm{l})$. Serum follicle stimulating hormone concentration was $2 \mathrm{IU} / 1$ (normal 3-20 IU/1), luteinising hormone concentration $3 \mathrm{IU} / 1$ (normal 5-20 IU/1), and testosterone concentration $3 \mathrm{nmol} / \mathrm{l}(0.87 \mathrm{ng} /$ $\mathrm{ml}$ ) (normal in men $10-35 \mathrm{nmol} / 1(2 \cdot 9-10 \cdot 1 \mathrm{ng} / \mathrm{ml})$ ). Serum thyroxine concentration was $40 \mathrm{nmol} / 1(3.1 \mu \mathrm{g} / 100 \mathrm{ml}$ ) (normal $60-150 \mathrm{nmol} / 1$ $(4 \cdot 7-11 \cdot 7 \mu \mathrm{g} / 100 \mathrm{ml}$ )), free thyroxine index 31 (normal 50-140), and serum thyroid stimulating hormone concentration $1 \mathrm{mU} / 1$ (normal $<4 \mathrm{mU} / \mathrm{l})$. Plasma cortisol concentration was $47 \mathrm{nmol} / \mathrm{l}(1 \cdot 7 \mu \mathrm{g} / 100 \mathrm{ml})$ (normal value at $0800>150 \mathrm{nmol} / \mathrm{l}(>5.4 \mu \mathrm{g} / 100 \mathrm{ml})$ ).

Adrenal and thyroid hormone replacement was begun. Bromocriptine treatment was started at $2.5 \mathrm{mg}$ daily increasing to $15 \mathrm{mg}$ daily in divided doses over one week; this was continued uninterrupted throughout his care. Subjective visual improvement occurred within 
48 hours, and improvement in visual fields was recorded within three weeks, when visual acuity in each eye was much improved (right $6 / 5$, left $6 / 9$ ) and serum prolactin concentration had fallen progressively to $31600 \mathrm{mU} / \mathrm{l}$. Reduction in the size of the tumour was shown by computed tomography over several months (fig (B)) and was maintained at least until August 1982, when the serum prolactin concentration reached a nadir of $5020 \mathrm{mU} / 1$. Steroid and thyroid replacement treatment were withdrawn, and he remained well with biochemical euthyroidism (serum thyroxine concentration $92 \mathrm{nmol} / 1(7 \cdot 1 \mu \mathrm{g} / 100$ $\mathrm{ml}$ ), free thyroxine index 87).

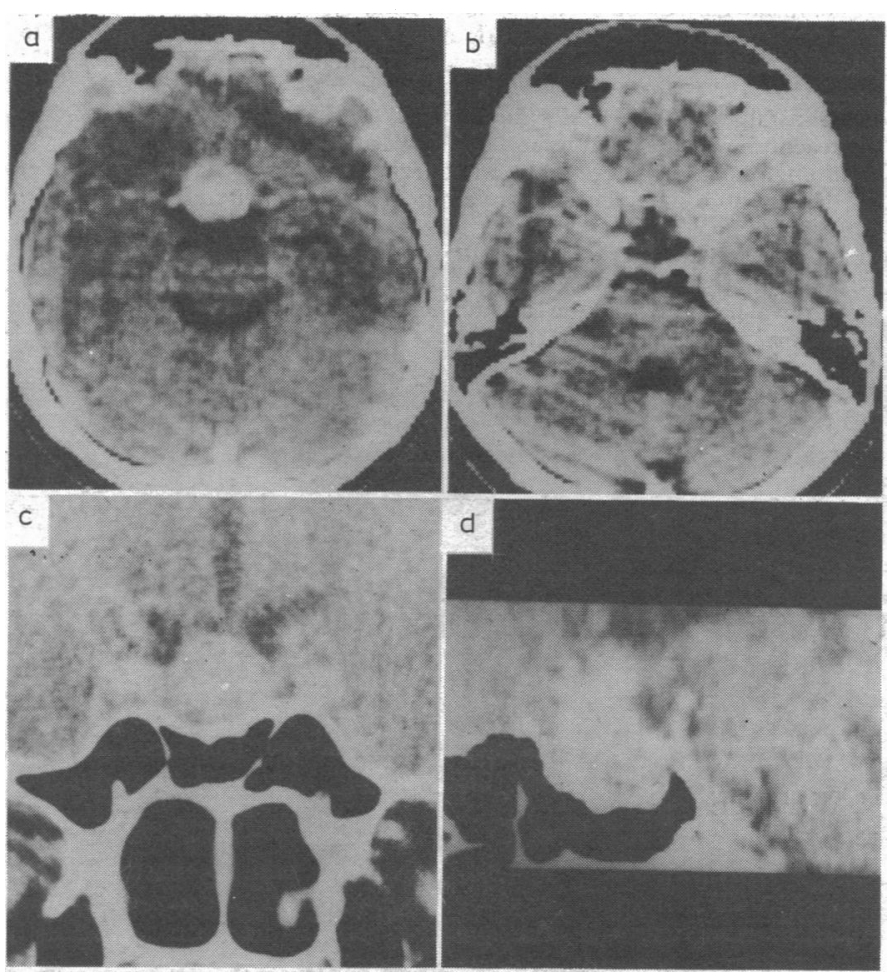

Serial computed tomograms of macroprolactinoma during treatment with bromocriptine. A: November 1981, before treatment. A large pituitary tumour with suprasellar extension is evident. B: June 1982, after six months' treatment. Tumour is no longer seen in upper part of pituitary fossa. C: September 1982, after nine months' treatment. Suprasellar regrowth of tumour evident on coronal view. D: January 1983. A preoperative sagittal reconstruction shows substantial suprasellar extension of tumour.

In September 1982, while he was still taking bromocriptine $15 \mathrm{mg}$ daily, his visual acuity was normal (right $6 / 5$, left $6 / 6$ ) and visual fields were normal to a low intensity object, but computed tomography showed expansion of the tumour (fig (C)) and the serum prolactin concentration had increased to $10000 \mathrm{mU} / \mathrm{l}$. The dose of bromocriptine was subsequently increased to $30 \mathrm{mg}$, then $40 \mathrm{mg}$, daily in divided doses, but he developed symptoms of hypopituitarism, with recurrence of secondary hypothyroidism (serum thyroxine concentration $28 \mathrm{nmol} / 1(2 \cdot 2 \mu \mathrm{g} / 100 \mathrm{ml})$, free thyroxine index 20 , and serum thyroid stimulating hormone concentration $1.9 \mathrm{mU} / \mathrm{l})$. Headaches returned, and a computed tomogram showed continued tumour growth (fig (D)).

Shortly before transfrontal hypophysectomy in January 1983 bitemporal hemianopia to a low intensity object was found, although visual acuity remained substantially unimpaired (right $6 / 9$, left $6 / 6$ ). Serum prolactin concentration was $42000 \mathrm{mU} / 1$. At operation tumour was found growing through a fibrous capsule to affect the optic chiasm and was resected. There was no evidence of haemorrhage into the tumour. Histological examination showed a chromophobe adenoma, and the cells produced prolactin in tissue culture. Production of prolactin by the cultured cells was not inhibited by concentrations of bromocriptine as high as $1 \mu \mathrm{mol} / 1(650 \mu \mathrm{g} / 1$ free base $)$.

Postoperatively his headaches abated and there was an immediate subjective visual improvement. Serum prolactin concentration was $12000 \mathrm{mU} / \mathrm{l}$ one week after the operation, when he was taking bromocriptine $20 \mathrm{mg}$, thyroxine $0.1 \mathrm{mg}$, and cortisone acetate $37.5 \mathrm{mg}$ daily.

\section{Discussion}

This patient clearly responded to treatment with bromocriptine initially, with a fall in the serum prolactin concentration, improvement in visual acuity and peripheral fields, and shrinkage of the tumour shown by computed tomography. At no time, however, did prolactin concentrations fall into the normal range. Subsequent recrudescence of tumour and rise in serum prolactin concentrations occurred during continued bromocriptine treatment and persisted despite an increase in the dosage of bromocriptine. The inability of high concentrations of bromocriptine to suppress production of prolactin by cultured tumour cells suggests that regrowth of the tumour was due to a population of cells resistant to dopamine agonist action.

One previous report described transient visual loss with suprasellar enlargement of a prolactinoma in the fifth month of bromocriptine treatment, ascribed to pituitary apoplexy. ${ }^{5}$ In our case, however, neither the computed tomograms nor the operative findings were compatible with a haemorrhage into the tumour being the cause of the expansion but indicated instead actual tumour growth.

Regrowth of a macroprolactinoma during continuing bromocriptine treatment, after an initial reduction in size due to the bromocriptine has not to our knowledge been described previously. The incidence of this event is unknown. It was not seen in a recent series of 29 patients, five of whom were treated for over one year. ${ }^{2}$ Nevertheless, although such a course may be uncommon, it represents an additional potential problem in the long term management of macroprolactinomas with bromocriptine and emphasises the need for close surveillance, especially of patients whose prolactin concentration fails to fall to normal during bromocriptine treatment.

We thank Dr John Game and Professor Keith Bradley, who initiated the case; Dr Isla Williams for repeated visual field charting; Mr K Sui for operating; Dr Peter Fuller for tissue culture; and Miss $\mathrm{H}$ Hammond for typing the manuscript.

ADDENDUM-Since acceptance of our paper our attention has been drawn to a paper by Dallabonzana D, Spelta B, Oppizzi G, et al, entitled "Reenlargement of macroprolactinomas during bromocriptine treatment: report of two cases" ( $f$ Endocrinol Invest 1983;6:47-50). We believe that our case is still unique as the first case described by Dallabonzana et al is that of pituitary apoplexy during bromocriptine treatment and the second showed only transient expansion, possibly related to accelerated bromocriptine clearance caused by spiramycin treatment. In neither case was there sustained tumour growth during continued bromocriptine treatment nor was resistance to bromocriptine shown in tissue culture.

\section{References}

${ }^{1}$ McGregor AM, Scanlon MF, Hall R, Hall K. Effects of bromocriptine on pituitary tumour size. $\mathrm{Br} M e d \mathcal{F} 1979$;ii:700-3.

2 Chiodini P, Liuzzi A, Cozzi R, et al. Size reduction of macroprolactinomas by bromocriptine or lisuride treatment. $\mathcal{F}$ Clin Endocrinol Metab 1981; $53: 737-43$.

${ }^{3}$ Wass JAH, Williams J, Charlesworth $\mathrm{M}$, et al. Bromocriptine in management of large pituitary tumours. $B r$ Med $f 1982 ; 284: 1908-11$.

4 Thorner MO, Perryman RL, Rogol AD, et al. Rapid changes of prolactinoma volume after withdrawal and reinstitution of bromocriptine. $\mathcal{F}$ Clin Endocrinol Metab $1981 ; 53: 480-3$.

5 Sobrinho LG, Nunes MC, Calhaz-Jorge C, et al. Effect of treatment with bromocriptine on the size and activity of prolactin producing tumours. Acta Endocrinol 1981 ;96:24-9. 